\title{
Pengaruh Suplementasi Asam Humat Pada Pakan Terhadap Pertumbuhan dan Jumlah Total Bakteri Pada Saluran Pencernaan Ikan Lele (Clarias sp.)
}

\section{Effect of Humic Acid Supplementation in Feed on The Growth and The Total Number of Bacteria in The Digestive Tract of Catfish (Clarias sp.)}

\author{
Muhammad Reynaldy Thoriq Al Islam ${ }^{1}$, Muhammad Arief ${ }^{2}$, Darmawan Setia Budi ${ }^{1,2 *}$ \\ ${ }^{1}$ Program Studi Akuakultur PSDKU Banyuwangi, Fakultas Perikanan dan Kelautan, Universitas \\ Airlangga, Jalan Wijaya Kusuma No. 113, Banyuwangi, Jawa Timur 68425, Indonesia. \\ ${ }^{2}$ Departemen Akuakultur, Fakultas Perikanan dan Kelautan, Universitas Airlangga, Kampus C, Jalan \\ Mulyorejo, Surabaya, Jawa Timur 60115, Indonesia. \\ *Corresponder author : darmawansetiabudi@fpk.unair.ac.id
}

Submited: 22 June 2021 Revised: 02 July 2021 Accepted: 22 July 2021 Publish: 31 July 2021

\begin{abstract}
Abstrak
Ikan lele (Clarias sp.) merupakan salah satu komoditas unggulan perikanan Indonesia yang produksinya terus ditingkatkan. Asam humat diketahui dapat membantu meningkatkan pertumbuhan pada beberapa jenis ikan dan diharapkan dapat diaplikasikan pada ikan lele. Penelitian ini bertujuan untuk mengetahui pengaruh pemberian asam humat pada pakan komersil terhadap pertumbuhan dan jumlah total bakteri pada saluran pencernaan ikan lele (Clarias sp.). Sebanyak 300 ekor ikan lele dengan panjang rata-rata $5,76 \pm 0,21 \mathrm{~cm}$ serta berat rata rata 27,92 $\pm 0,39 \mathrm{~g}$ digunakan pada 5 perlakuan (4 ulangan/perlakuan) suplementasi asam humat pada pakan dengan dosis berbeda yaitu P1 (tanpa asam humat/kontrol), P2 (0.5 \%), P3 (1.0\%), P4 (1.5\%), dan P5 (2.0\%). Pemeliharaan dilakukan selama 40 hari dengan pemberian pakan perlakuan 3 kali sehari sebanyak 5\% dari bobot tubuh. Parameter yang diamati adalah pertumbuhan panjang mutlak $(\mathrm{cm})$, pertumbuhan bobot mutlak $(\mathrm{g})$, laju pertumbuhan spesifik (\%), dan total bakteri pada saluran pencernaan (koloni/g). Berdasarkan hasil penelitian diketahui bahwa perlakuan memberikan pengaruh nyata terhadap pertumbuhan dan jumlah koloni bakteri dengan dosis pemberian asam humat yang optimal sebesar 0.5.
\end{abstract}

Kata kunci: Perlakuan, Dosis, Kontrol, Koloni

\begin{abstract}
Catfish (Clarias sp.) is one of Indonesia's leading fishery commodities whose production continues to be increased. Humic acid is known to help increase growth in several types of fish and is expected to be applied to catfish. This study aims to determine the effect of humic acid in commercial feed on the growth and total number of bacteria in the digestive tract of catfish (Clarias sp.). A total of 300 catfish with an average length of $5.76 \pm 0.21 \mathrm{~cm}$ and an average weight of $27.92 \pm 0.39 \mathrm{~g}$ were used in 5 treatments (4 replicates/treatments) of humic acid supplementation in feed with different doses, namely P1 (without humic acid/control), P2 (0.5\%), P3 (1.0\%), P4 (1.5\%), and P5 (2.0\%). Maintenance was carried out for 40 days by feeding treatment 3 times a day as much as $5 \%$ of body weight. Parameters observed were absolute length growth $(\mathrm{cm})$, absolute weight growth $(\mathrm{g})$, specific growth rate $(\%)$, and total bacteria in the digestive tract (colonies/g). Based on the results of the study, it was found that the treatment had a significant effect on the growth and number of bacterial colonies with the optimal dose of humic acid of 0.5 .
\end{abstract}

Keyword : Behavior, Doses, Control, Colony 
Journal of Aquaculture Science

DOI: https://doi.org/10.31093/joas.v6i1IS.151
July 2021 Vol 6 Issue Spesial: 1-14

Online pada http://joas.co.id

\section{PENDAHULUAN}

Ikan lele (Clarias sp.) salah satu komoditan ikan yang memiliki nilai ekonomis yang tinggi dan menjadi unggulan produksi perikanan di Indonesia. Data dari Laporan Tahunan Direktorat Produksi Kementrian Kelautan dan Perikanan (KKP) tahun 2018 menyatakan bahwa produksi ikan lele (Clarias sp.) memiliki produksi sebesar $85.496,85$ ton naik 79,15 persen dari tahun sebelumnya sebesar $67.671,84$ ton (KKP, 2018). Peningkatan yang terus menerus secara signifikan mengindikasikan sejalan lurus dengan permintaan pasar yang setiap tahun terus meningkat.

Budidaya ikan lele (Clarias sp.) membutuhkan pakan dengan kandungan nutrien yang tepat agar mampu mengoptimalkan pertumbuhannya. Jumlah dan kebutuhan nutrien yang sesuai dan unsur atau senyawa lainnya yang terdapat dalam pakan dapat mengoptimalkan pertumbuhan ikan lele (Hendri, dkk. 2012).

Sekitar $60-70 \%$ dari total biaya produksi yang dikeluarkan pada kegiatan budidaya ikan umumnya adalah biaya pakan (Hendri, et.al. 2012). Pemanfaatan bahan tambahan dalam pakan merupakan salah satu cara alternatif untuk mengurangi pemberian pakan tetapi pertumbuhan tetap stabil seperti pemberian pakan alami, atau dapat dikombinasikan dengan pakan tambahan yang mempercepat pertumbuhan (Arief, dkk. 2014).

Pertumbuhan ikan lele juga dipengaruhi oleh jumlah bakteri yang terdapat dalam saluran pencernaan, dalam fungsinya asam humat mampu memperbanyak bakteri positif untuk membantu penyerapan nutrisi dalam usus dengan mekanisme melindungi vili usus dari bakteri negatif sehingga didalam usus bakteri positif lebih dominan dan berkembang karena adanya asam humat (Arief, et al., 2019). Bakteri memiliki peran aktif terhadap saluran penceranaan sebagai pengurai senyawa organik menjadi sederhana, mekanisme kerja dari bakteri sendiri adalah menghasilkan beberapa enzim yang membantu untuk menghidrolisis nutrsi dalam pakan agar mempermudah menyerapan dan proses pencernaan dalam saluran pencernaan (Putra, 2010).

Berkaitan dengan hal tersebut, asam humat adalah bahan tambahan yang dapat digunakan untuk mempercepat pertumbuhan tanaman maupun ikan 
Journal of Aquaculture Science

DOI: https://doi.org/10.31093/joas.v6i1IS.151
July 2021 Vol 6 Issue Spesial: 1-14

Online pada http://joas.co.id
(Stevenson, 1982 dalam Ihdaryanti, 2011).

Humat merupakan suatu senyawa organik yang relatif resisten, bersifat koloid, berasal dari dekomposisi bahan organik, larut dalam basa dan mengendap dalam asam. Asam humat adalah hasil dari penguraian dan modifikasi sisa organisme baik dari hewan maupun tumbuhan (Kodama dan Denso, 2007). Cara kerja asam humat dalam meningkatkan pertumbuhan adalah dengan mengaktifkan dan meningkatkan produktivitas enzim di dalam saluran pencernaan sehingga dapat memicu penyerapan nutrisi dalam pakan dan menjadikannya sebagai sumber protein yang berdampak dalam pertumbuhan ikan budidaya (Yilmaz, et al. 2018). Berdasarkan uraian-uraian tersebut, penambahan asam humat pada pakan diharapkan dapat meningkatkan pertumbuhan ikan lele. Penelitian ini bertujuan untuk mengetahui pengaruh pemberian asam humat pada pakan komersil terhadap pertumbuhan dan jumlah total bakteri pada saluran pencernaan ikan lele.

\section{METODE PENELITIAN}

\section{Waktu dan lokasi penelitian}

Penelitian dilaksanakan pada tanggal 27 Februari 2020 bertempat di
Laboratorium Anatomi Fakultas

Perikanan dan Kelautan PSDKU

Universitas Airlangga di Banyuwangi.

\section{Rancangan penelitian}

Sebanyak 300 ekor ikan lele dengan panjang rata-rata $5,76 \pm 0,21 \mathrm{~cm}$ serta berat rata rata $27,92 \pm 0,39 \mathrm{~g}$ digunakan pada 5 perlakuan (4 ulangan/perlakuan) suplementasi asam humat pada pakan dengan dosis berbeda yaitu P1 (tanpa asam humat/kontrol), P2 (0.5\%), P3 (1.0\%), P4 (1.5\%), dan P5 (2.0\%). Pemeliharaan dilakukan selama 40 hari dengan pemberian pakan perlakuan 3 kali sehari sebanyak 5\% dari bobot tubuh. Parameter yang diamati adalah pertumbuhan panjang mutlak $(\mathrm{cm})$, pertumbuhan bobot mutlak (g), laju pertumbuhan spesifik (\%), dan total bakteri pada saluran pencernaan (koloni/g).

Persiapan pemberian pakan dilakukan dengan menimbang jumlah pakan yang akan diberikan dengan perhitungan $5 \%$ dari berat massa ikan. Asam humat yang sudah disiapkan dilarutkan dalam air dengan dosis yang sudah ditentukan dan ditampung pada botol semprot. Pemberian zat aktif Calcium Ligno Sulfunat (Progol, PT Indosco Dwijaya Sakti, Surabaya) sebanyak $0,02 \%$ ditambahkan untuk 
Journal of Aquaculture Science

DOI: https://doi.org/10.31093/joas.v6i1IS.151

merekatkan larutan asam humat pada pakan. Semprot pakan yang sudah disiapkan hingga tercampur dalam pakan. Setelah itu kering anginkan sejenak untuk hasil yang maksimal bahwa larutan asam humat tercampur merata pada pakan komersil.

\section{Metode Pengumpulan Data}

Sampling untuk mengukur parameter pertumbuhan dilakukan setiap 10 hari dengan mengukur panjang dan berat seluruh individu pada setiap ulangan. Pertumbuhan panjang mutlak dihitung sesuai dengan rumus yang dikemukakan oleh Berian, dkk (2013):

\section{Lm = TL1 - TL0}

Dimana:
$\mathrm{Lm}=$ pertumbuhan panjang mutlak (cm),

TL1 = panjang total pada akhir pemeliharaan $(\mathrm{cm})$,

TLO = panjang total pada awal pemeliharaan $(\mathrm{cm})$.

Pertumbuhan bobot mutlak (W) dihitung menggunakan rumus arifin dan rupawan (1997) dalam Wijayanti (2010):

$$
\mathbf{W}=\mathbf{W}_{\mathbf{t}}-\mathbf{W}_{\mathbf{0}},
$$

Dimana:

$\mathrm{W}=$ pertumbuhan bobot $(\mathrm{g})$,

$\mathrm{W}_{\mathrm{t}}=$ bobot rata-rata ikan pada waktu $t$ $(\mathrm{g})$,

$\mathrm{W}_{0}=$ bobot rata-rata ikan pada waktu awal penelitian $(\mathrm{g})$.
Laju pertumbuhan spesifik (Specific Growth Rate) digunakan untuk menentukan pertumbuhan secara spesifik dalam presentasi per hari. Rumus laju pertumbuhan menurut Steffens (1989) dalam Rudiyanti dan Ekasari (2009) sebagai berikut:

$$
\mathbf{S G R}=\frac{\operatorname{In} W t-\operatorname{In} W o}{t_{1-} t_{0}} \times \mathbf{1 0 0 \%},
$$

Dimana:

SGR = Laju pertumbuhan berat spesifik (\% per hari),

$\mathrm{Wt}=$ Bobot biomassa pada akhir penelitian (gram),

Wo $=$ bobot biomassa pada awal penelitian (gram),

$\mathrm{t}_{1}=$ waktu akhir penelitian (hari), dan

$\mathrm{t}_{0}=$ waktu awal penelitain (hari)

Analisis Total Bakteri dengan mengambil masing-masing ikan pada ulangan disetiap perlakuan sebanyak satu ekor, kemudian dilakukan pembedahan untuk mengambil bagian ususnya. Usus ikan uji diambil sebanyak 0,1 g lalu dimasukkan ke dalam tabung mikro serta ditambahkan larutan $\mathrm{NaCl}$ sebanyak 0,9 $\mathrm{mL}$. Sampel usus dihomogenisasi dengan cara divortex. Selanjutnya dilakukan pengenceran berseri. Pada pengenceran $10^{-2}, 10^{-4}$, dan $10^{-6}$ masing-masing sampel diambil sebanyak $0,05 \mathrm{~mL}$ dengan menggunakan mikro pipet, lalu disebar merata pada media Natrium Agar (NA) dengan menggunakan trygalsky. 
Journal of Aquaculture Science

DOI: https://doi.org/10.31093/joas.v6i1IS.151
July 2021 Vol 6 Issue Spesial: 1-14

Online pada http://joas.co.id
Selanjutnya kultur bakteri di inkubasi selama 24 jam.

Setelah itu dilakukan perhitungan dengan rumus (Miskiyah, 2011 dalam Rose D., dkk, 2018) sebagai berikut: TPC (koloni/g) = Jumlah koloni per cawan $\times(1 /$ faktor pengenceran $)$.

\section{Analisis data}

Data yang diperoleh kemudian dilakukan sidik ragam atau analisa varians (ANOVA) untuk menentukan pengaruh atau tidak perlakuan terhadap hasil penelitian, jika berpengaruh nyata maka dilakukan dengan Duncan multiple range test (DMRT) untuk menentukan perlakuan yang optimal pada taraf kepercayaan $95 \%$ sampai $99 \%$ untuk membandingkan nilai antar perlakuan hasil dari penelitian diuraikan secara deskriptif. Sedangkan untuk parameter penunjang lain seperti kualitas air dianalisis secara deskriptif dengan bantuan gambar dan tabel.

\section{Pertumbuhan Panjang Mutlak}

Data pertumbuhan panjang mutlak penelitian ikan lele (Clarias sp.) dengan pemberian asam humat selama 40 hari pada masig masing perlakuan dapat dilihat pada Tabel 1

Tabel 1. Pertumbuhan ikan lele (Clarias sp.) yang diberi pakan dengan suplementasi asam humat selama 40 hari.

\begin{tabular}{cc} 
40 hari. & Panjang Mutlak \pm SD $(\mathrm{cm})$ \\
\hline Perlakuan & $2.84^{\mathrm{b}} \pm 0.42$ \\
P1 & $4.02^{\mathrm{a}} \pm 0.34$ \\
P3 & $2.92^{\mathrm{b}} \pm 0.47$ \\
P4 & $3.06^{\mathrm{b}} \pm 0.39$ \\
P5 & $2.73^{\mathrm{b}} \pm 0.58$
\end{tabular}

Keterangan : Nilai rata-rata dengan huruf superskrip yang berbeda dalam satu kolom menunjukkan perbedaan yang signifikan $(\mathrm{P}<0,05)$. $(\mathrm{P}<0,05)$. $\mathrm{P} 1$ : Kontrol; $\mathrm{P} 2$ : asam humat $0,5 \%$; $\mathrm{P} 3$ : asam humat $1 \%$; P4 asam humat $1,5 \%$; dan P5: asam humat $2 \%$.

Pemeliharaan pada penelitian memberikan pengaruh yang nyata teradap pertumbuhan mutlak $(\mathrm{P}<0,05)$. Nilai pertumbuhan panjang mutlak ikan lele optimum pada perlakuan dengan pemberian asam humat $0,5 \%$. Setelah dilakukan uji Duncan, pertumbuhan mutlak tertinggi terdapat pada P2 dengan nilai $4.02 \pm 0.34 \mathrm{~cm}$ dan yang terkecil P5 $2.73 \pm 0.58 \mathrm{~cm}$. P3, P4, dan P1 tidak berbeda nyata. Grafik panjang ikan lele (Clarias sp.) selama masa pemeliharaan dapat dilihat pada gambar 6 .

Hasil uji ANOVA sampling minggu pertama hingga minggu ketiga, menunjukkan bahwa pemberian asam 
humat mampu memberikan pengaruh yang berbeda nyata $(P<0,05)$. Nilai panjang perminggu ikan lele meningkat dengan P3 merupakan perlakuan dengan pertambahan panjang paling tinggi pada minggu pertama $5,83 \pm 0,1 \mathrm{~cm}$, sedangkan pada minggu kedua dan ketiga perlakuan $\mathrm{P} 2$ dengan pertambahan panjang paling tinggi pada minggu kedua $6,95 \pm 0,2 \mathrm{~cm}$ dan minggu ketiga 9,72 \pm $0,3 \mathrm{~cm}$. Perlakuan P5 adalah perlakuan terendah selama minggu pertama sampai ketiga.

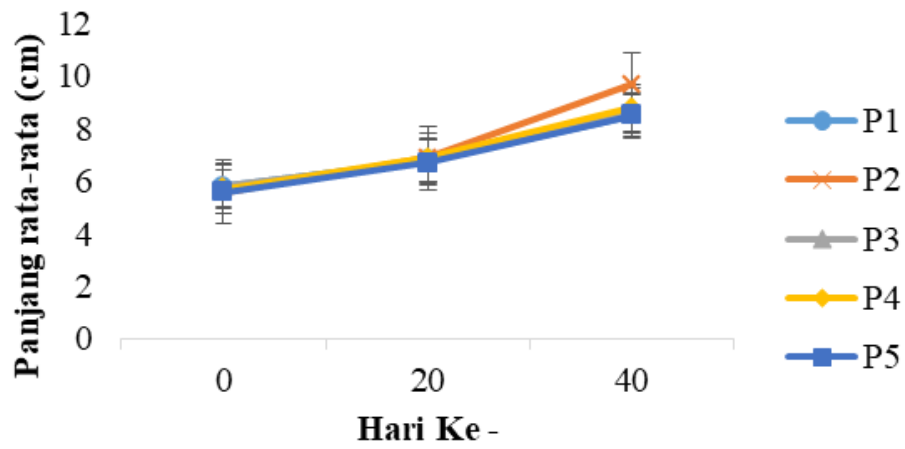

Gambar 1. Panjang rata-rata_ikan lele (Clrias sp.) dalam perlakuan pemberian asam humat yang dipelihara selama 40 hari. P1: Kontrol; P2: asam humat 0,5\%; P3: asam humat 1\%; P4 asam humat $1,5 \%$; dan P5: asam humat $2 \%$.

\section{Pertumbuhan Bobot Mutlak}

Data berat rata-rata ikan lele pada masing masing perlakuan selama 40 hari pemeliharaan dapat dilihat pada Tabel 2. Selanjutnya, pertumbuhan berat mutlak setelah dianalisa menggunakan analisa ANOVA hasil menunjukkan bahwa ada perbedaan nyata dari tiap perlakuan $(\mathrm{P}<$
0,05). Nilai pertumbuhan berat mutlak ikan lele meningkat setiap minggunya. Pertumbuhan berat mutlak didapatkan hasil paling baik pada P2 dengan nilai $2,66 \pm 0,12$ gram, kemudian yang terendah adalah P5 sebesar 2,16 $\pm 0,11$ gram.

Tabel 2. Pertumbuhan berat mutlak ikan lele (Clarias sp.) yang dipelihara dengan pemberian asam humat selama 40 hari

\begin{tabular}{cc}
\hline Perlakuan & Berat Mutlak \pm SD (gram) \\
\hline P1 & $2.38^{\mathrm{bc}} \pm 0.11$ \\
P2 & $2.66^{\mathrm{a}} \pm 0.12$ \\
P3 & $2.49^{\mathrm{ab}} \pm 0.15$ \\
P4 & $2.29^{\mathrm{bc}} \pm 0.12$ \\
P5 & $2.16^{\mathrm{c}} \pm 0.11$
\end{tabular}

Keterangan : Nilai rata-rata dengan huruf superskrip yang berbeda menunjukkan perbedaan yang signifikan $(\mathrm{P}<0,05)$. $\mathrm{P} 1$ : Kontrol; $\mathrm{P} 2$ : asam humat 0,5\%; $\mathrm{P} 3$ : asam humat $1 \%$; $\mathrm{P} 4$ asam humat $1,5 \%$; dan P5: asam humat $2 \%$. 
Journal of Aquaculture Science

DOI: https://doi.org/10.31093/joas.v6i1IS.151
July 2021 Vol 6 Issue Spesial: 1-14

Online pada http://joas.co.id
Hasil analisa ANOVA menunjukkan bahwa pemberian asam humat terhadap ikan lele mempengaruhi berat pada setiap minggunya $(\mathrm{P}<0,05)$. Perlakuan paling tinggi adalah perlakuan
P2 yaitu pada minggu ketiga $67,6 \pm 2,1$ gram, sedangkan perlakuan paling terendah pada minggu ketiga yaitu P5 $60.5 \pm 1,9$ gram. Grafik berat ikan lele pada pemeliharaan selama 40 hari dapat dilihat pada gambar 2 .

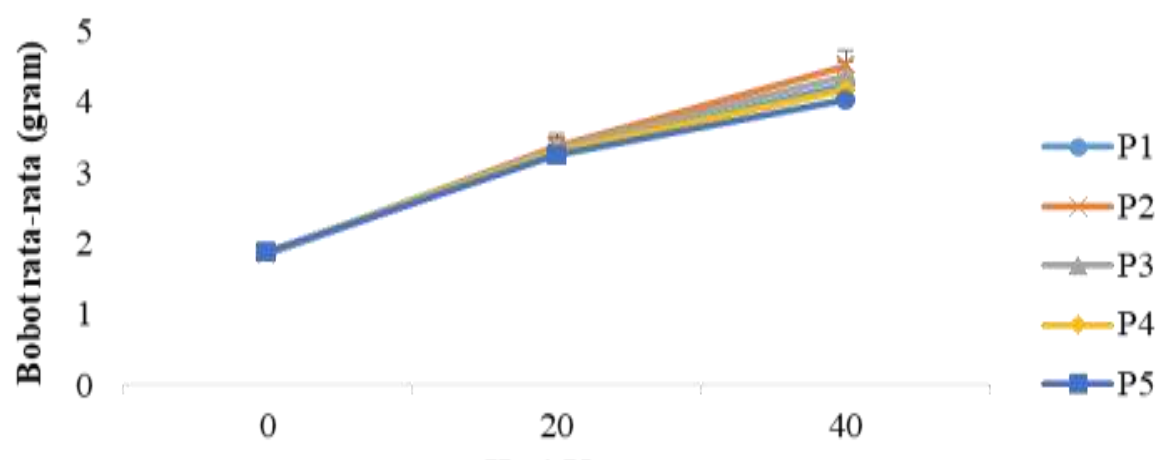

Hari Ke -

Gambar 2. Berat rata-rata ikan lele (Clarias sp.) yang dipelihara selama 40 hari. P1: Kontrol; P2: asam humat $0,5 \%$; P3: asam humat 1\%; P4 asam humat 1,5\%; dan P5: asam humat $2 \%$.

Laju Pertumbuhan Spesifik (Spesific memberikan pengaruh berbeda nyata ( $\mathrm{P}$

\section{Growth Rate)}

Hasil analisis (ANOVA) yang dilakukan terhadap laju pertumbuhan spesifik dapat dilihat pada lampiran. Nilai laju pertumbuhan spesifik menunjukkan bahwa pemberian asam humat terhadap pertumbuhan ikan lele,
$<$ 0,05) terhadap laju pertumbuhan spesifik. Nilai laju pertumbuhan spesifik tertinggi terdapat pada perlakuan P2 $(0,99 \pm 0,04 \% /$ hari $)$ dan hasil terendah pada perlakuan P5 $(0,81 \pm 0,04 \% /$ hari $)$. Grafik laju pertumbuhan spesifik dapat dilihat pada gambar 3 .

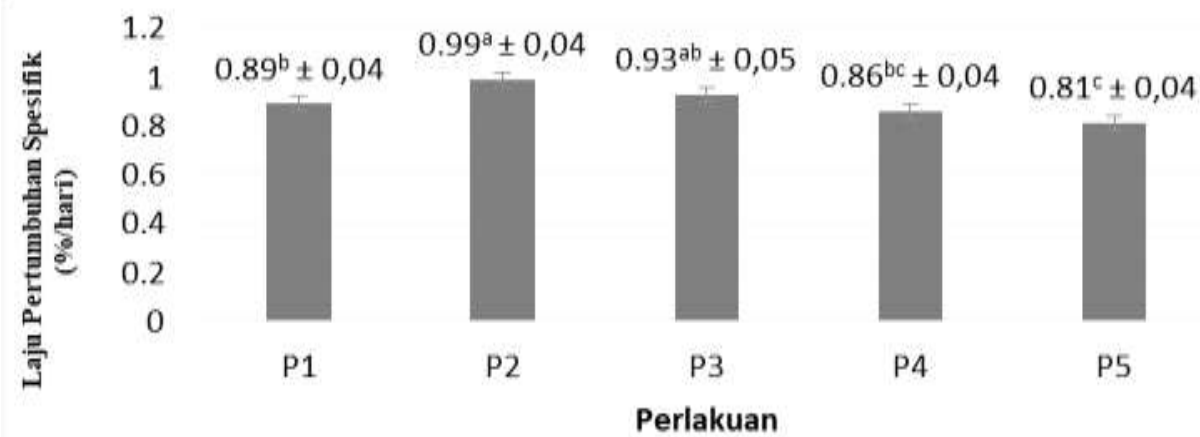

Gambar 3. Laju pertumbuhan spesifik ikn lele (Clarias sp.) yag dipelihara selama 40 hari. Hasil analisis ANOVA menunjukkan terdapat perbedaan yang signifikan ( $\mathrm{P}<0,05)$. P1: Kontrol; P2: asam humat $0,5 \%$; P3: asam humat 1\%; P4 asam humat 1,5\%; dan P5: asam humat $2 \%$. 


\section{Total Bakteri}

Berdasarkan hasil penelitian total bakteri pada saluran pencernaan ikan lele (Clarias sp.) dapat dilihat bahwa perlakuan 2 dengan pemberian asam humat sebanyak $0,5 \%$ memiliki dampak pertumbuhan bakteri yang sangat tinggi dibandingkan dengan perlakuan yang lain, data dapat dilihat pada tabel 2 .

Tabel 3. Jumlah koloni bakteri pengenceran $10^{-4}$ pada saluran pencernaan ikan lele yang dipelihara selama 40 hari

\begin{tabular}{cc}
\hline Perlakuan & Pengenceran $10^{-4} \pm$ SD (koloni/gram) \\
\hline P1 & $1.18^{\mathrm{e}} \pm 0.05$ \\
P2 & $2.57^{\mathrm{a}} \pm 0.08$ \\
P3 & $2.24^{\mathrm{b}} \pm 0.09$ \\
P4 & $2.08^{\mathrm{c}} \pm 0.09$ \\
P5 & $1.84^{\mathrm{d}} \pm 0.15$ \\
\hline
\end{tabular}

Keterangan : Nilai rata-rata dengan huruf superskrip yang berbeda menunjukkan perbedaan yang signifikan (P < 0,05). P1: Kontrol; P2: asam humat 0,5\%; P3: asam humat 1\%; P4 asam humat $1,5 \%$; dan P5: asam humat $2 \%$.

Pemeliharaan dengan pemberian asam humat terhadap ikan lele memberikan pengaruh yang nyata terhadap jumlah koloni bakteri yang tumbuh pada saluran pencernaan ikan lele $(\mathrm{P}<0,05)$. Jumlah koloni bakteri yang terdapat dalam saluran pencernaan ikan lele yang paling tinggi terdapat pada P2 dengan nilai $2,57 \pm 0,08 \mathrm{cfu} / \mu \mathrm{l}$ dan yang terkecil P1 1,18 $\pm 0,05 \mathrm{cfu} / \mu \mathrm{l} . \mathrm{P} 3$ dengan $\mathrm{P} 4$ berbeda nyata.

Hasil uji ANOVA menunjukkan bahwa pemberian asam humat memberikan pengaruh yang berbeda nyata $(\mathrm{P}<0,05)$ terhadap jumlah koloni bakteri pada saluran pencernaan ikan lele dengan pemeliharaan selama 40 hari. Perlakuan P2 merupakan perlakuan dengan jumlah koloni bakteri paling tinggi yaitu 2,66 $\pm 0,08 \mathrm{cfu} / \mu \mathrm{l}$ sedangkan perlakuan paling rendah terdapat pada perlakuan $\mathrm{P} 1$ yaitu $1,15 \pm 0,05 \mathrm{cfu} / \mu \mathrm{l}$.

\section{Kualitas Air}

Pengukuran kuaitas air pada penelitian ini meliputi suhu, $\mathrm{pH}, \mathrm{DO}$ dan amoniak. Nilai DO memiliki nilai yang hampir sama disetiap perlakuan yaitu berkisar antara 7,0-7,8 ppm, suhu berkisar antara $25-27^{\circ} \mathrm{C}, \mathrm{pH}$ berkisar 6,72-7,87, serta amoniak 0,05-0,1 ppm. Pengukuran dilakukan setiap seminggu sekali dengan mengirimkan sampel air ke laboratorium Matahari Sakti (MS).

\section{PEMBAHASAN}

Pemberian asam humat pada penelitian ini memberikan pengaruh signifikan pada panjang tubuh, berat, 
hingga jumlah bakteri yang terdapat dalam saluran pencernaan ikan lele setelah dipelihara selam 40 hari $(\mathrm{P}<$ 0,05). Asam humat merupakan bahan zat organik yang mampu meningkatkan pertumbuhan dalam bidang pertanian, hal ini juga berlaku pada bidang perikanan di mana senyawa dari asam humat mampu untuk mempercepat pertumbuhan dengan dosis sesuai kebutuhan dan konsumsi ikan (Yilmaz, et al. 2018).

Berdasarkan hasil penelitian, pemberian asam humat pada ikan lele menghasilkan peningkatan pertumbuhan panjang dan bobot tertinggi pada perlakuan P2 (dosis 0,5\%). Hasil positif juga diperoleh dari penelitian sebelumnya pada ikan nila (Mandasari, 2016). Dosis optimal aplikasi asam humat pada ikan nila adalah $1 \%$ (Rousdy dan Wijayanti, 2015). Hal ini menunjukkan bahwa aplikasi asam humat berbeda-beda bergantung pada spesies ikan yang dibudidaya.

Peningkatan pertumbuhan pada ikan akibat pemberian asam humat terjadi karena struktur asam humat yang berupa makro-koloid mampu membentuk lapisan seperti membran yang memungkinkan asam humat memberikan perlindungan pada lapisan mukosa yang ada dalam saluran pencernaan sehingga mampu mengoptimalkan penyerapan nutrien dalam pakan (Von Wandruszka, 2000). Hal ini juga terkait dengan kelimpahan bakteri positif yang dapat memicu mengaktifkan enzim, beberapa bakteri seperti Bacillus menghasilkan enzim seperti protease, lipase, amilase, dan selulase yang dapat membantu pencernaan dalam tubuh hewan (Wongsa dan Werukhamkul 2007).

Peningkatan kelimpahan bakteri pada saluran pencernaan ikan lele yang diberi asam humat ditunjukkan melalui peningkatan jumlah koloni bakteri pada saluran pencernaan (TPC) jika dibandingkan dengan kontrol. Selaras dengan pertumbuhan tertinggi jumlah koloni tertinggi juga terjadi pada perlakuan P2 (dosis 0,5\%). Semakin bertambahnya dosis asam humat yang diberikan pada pakan lele mengalami penurunan jumlah koloni bakteri tetapi penurunan pada masing masing perlakuan tidak terlalu signifikan dan masih terdapat perbedaan pemberian asam humat dibandingkan dengan kontrol. Selain berfungsi sebagai penghambat bakteri dan mengurangi tingkat mikotoksin, diduga asam humat mengandung fermentor yang mampu menghasilkan senyawa antimikroorganisme seperti asam laktat, 
Journal of Aquaculture Science

DOI: https://doi.org/10.31093/joas.v6i1IS.151
July 2021 Vol 6 Issue Spesial: 1-14

Online pada http://joas.co.id bakteriosin, dan renterin yang dapat menghambat patogen yang ada dalam saluran pencernaan ikan sehingga memicu peningkatan imunitas melalui aktivitas mikrofag (Anis dan Hariani, 2019).

Hal ini memicu pertumbuhan koloni bakteri yang membantu meningkatkan penyerapan nutrisi dalam pakan sehingga mempercepat pertumbuhan. Berbeda dengan hasil yang tidak menggunakan perlakuan asam humat cenderung memiliki jumlah koloni yang paling sedikit. Hasil pada perlakuan 5 dengan dosis asam humat paling tinggi sebanyak $2 \%$ juga tidak terlalu baik karena kandungan asam humat yang terlalu tinggi dan saluran pencernaan lele yang pendek mengakibatkan penyerapan pada nutrisi pakan terbuang melalui urine dan kandungan asam humat yang terlalu berlebihan juga ikut terbuang. Selain itu menurut Rousdy dan Wijayanti (2015) menyatakan bahwa pemberian asam humat dengan dosis yang berlebihan membuat parameter yang diamati mengalami penurunan.

Menurut Lusiastuti, dkk. (2017) Perlakuan penambahan kombinasi probotik mikroenkapsulasi mampu meningkatkan jumlah bakteri pada saluran pencernaan dan mampu meningkatkan sejalan dengan meningkatnya jumlah kononi bakteri. Mandasari (2016) menyatakan bahwa pemberian asam humat mampu menghasilkan jumlah bakteri sebanyak $4,1 \times 10^{6} \mathrm{cfu} / \mathrm{ml}$ dengan pemberian asam humat $400 \mathrm{mg} / \mathrm{kg}$. Berdasarkan pernyataan jumlah koloni bakteri erat kaitannya dengan laju pertumbuhan pada ikan, dengan kata lain semakin banyak tingkat bakteri yang ada dalam saluran pencernaan mampu menigkatkan laju pertumbuhan.

Hal ini karena bakteri mampu membantu produksi enzim sehingga penyerapan pada nutrisi pakan berjalan secara maksimal (Wongsa dan Werukhamkul 2007). Penggunaan asam humat juga tidak jauh berbeda bahkan cenderung lebih baik karena penggunaan dengan dosis $\quad 0,5 \%$ mampu meningkatkan jumlah koloni bakteri hingga pengenceran $10^{-4}$. Perlakuan dengan jumlah bakteri yang tinggi berjalan searah dengan pertumbuhan dan bobot terbaik dari semua perlakuan. Hal ini membuktikan bahwa pemberian asam humat mampu meningkatkan pertumbuhan dengan meningkatkan bakteri saluran pencernaan ikan lele sehingga nutrisi yang terdapat dalam pakan mampu diserap secara makasimal. 
Journal of Aquaculture Science

DOI: https://doi.org/10.31093/joas.v6i1IS.151
July 2021 Vol 6 Issue Spesial: 1-14

Online pada http://joas.co.id
Kualitas air dalam budidaya ikan merupakan faktor utama yang harus dijaga. Penuruanan kualitas air dapat mengakibatkan pertumbuhan lambat, timbul penyakit, hingga kematian. Beberapa parameter sebagai penunjang pada penelitian ini adalah Suhu, $\mathrm{pH}, \mathrm{DO}$, dan Amoniak. Nilai kisaran suhu selama penelitian berkisar antara $25-27^{\circ} \mathrm{C}$. Hal ini sesuai dengan pendapat Prihartono dkk (2000). yang memberikan batasan nilai toleransi suhu pada budidaya ikan lele kisaran $20-30^{\circ} \mathrm{C}$. Perubahan suhu yang drastis akan mengakibatkan perubahan metabolisme dalam tubuh biota serta secara langsung akan mempengaruhi pertumbuhan (Rahardjo dkk., 2011). Hasil pengukuran pH dan oksigen terlarut (DO) berada pada kisaran normal dengan angka kisaran untuk pH 6-7 sedangkan DO kisaran 67,8 ppm. Hal ini sesuai dengan pendapat Khairun dan Amri (2002) bahwa pH optimal dalam pemeliharaan lele berkisar 6,5-8, sedangkan menurut Medinawati et al (2011) menyatakan bahwa nilai minimu DO dalam perairan sudah mendukung kehidupan organisme secara normal. Dalam budidaya sisa pakan dalam bentuk feses atau yang tidak termakan menjadi faktor utama penurunan kualitas air ditandai dengan kandungan amonia yang tinggi. Konsentrasi amonia selama penilitian berkisar 0,05-0,1 mg/l. Hal ini masih dalam kondisi normal, dimana batas toleransi konsentrasi amoniak didalam air tidak lebih dari $1 \mathrm{mg} / \mathrm{l}$ (Anonimus, 2010).

Pemberian asam humat mampu memberikan efek terhadap pertumbuhan, bobot, dan jumlah bakteri pada saluran pencernaan ikan lele, Seperti pada hasil penelitian pemeliharaan ikan lele dengan pemberian asam humat selama 40 hari. Hal ini menandakan bahwa pemberian asam humat mampu untuk meningkatkan pertumbuhan ikan lele dengan konsentrasi dosis optimum sebesar $0,5 \%$ dari bobot pemberian pakan.

\section{KESIMPULAN}

Pemberian suplementasi asam humat pada pakan ikan lele (Clarias sp.) dapat meningkatkan pertumbuhan dan bobot mutlak dibandingkan dengan kontrol dengan dosis optimal $0,5 \%$. Asam Humat mampu meningkatkan jumlah koloni bakteri dimana jumlah total bakteri pada saluran pencernaan ikan lele sebanding lurus dengan pertumbuhan ikan lele.

\section{Ucapan Terima Kasih}

Terimakasih kepada seluruh pihak yang membantu penelitian ini. 
Journal of Aquaculture Science

DOI: https://doi.org/10.31093/joas.v6i1IS.151
July 2021 Vol 6 Issue Spesial: 1-14

Online pada http://joas.co.id

Kakap Putih (Lates calcarfer) dengan Pemberian Pakan yang Berbeda. Maspari Journal. Vol 5 No 1 .

Chen, C., Liu, J., Lu, F., Yang, M., Lee, Y. \& Huang, T. The Effect of Humic Acid on The Adhesibility of Neutrophils. Thrombosis Research. 2003; 108: 6776.doi:10.1016/S0049-3848(02)00384-5

Feliatra, I. Efendi, dan E. Suryadi. 2004. Isolasi dan Identifikasi Bakteri Probiotik dari Ikan Kerapu Macan (Ephinephelus fuscogatus) dalam Upaya Efisiensi Pakan Ikan. Jurnal Natur Indonesia. 6 (2): 75-80.

Alamsyah, S., H. Y. Aziz, Sriwulan, dan K. G. Wiryawan. 2009. Mikroflora Saluran Pencernaan Ikan Gurame (Osphronemus gouramy Lacepede).Torani. Jurnal Ilmu Kelautan dan Perikanan. 19 (1): 66-73.

Amalia, R., Subandiyono dan E. Arini. 2013. Pengaruh Penggunaan Papain Terhadap Tingkat Pemanfaatan Protein Pakan dan Pertumbuhan Lele Dumbo (Clarias gariepinus). Journal of Aquaculture Management and Technology Vol 2(1): $136-143$.

Anis M, Y., dan D Hariyani. 2019. Pemberian Pakan Komersial dengan Penambahan EM4 (Effective Microorganisme 4) untuk Meningkatkan Laju Pertumbuhan Lele ( Clarias sp.). Jurnal Riset Biologi dan Aplikasinya.

Anonimus 2010. Peraturan Pemerintah Republik Indonesia Nomor 82 tahun 2001 tentang Pengelolaan Kualitas Air dan Pengendalian Pencemaran Air. Presiden Republik Indonesia.

Arif, M., Alagawany, M., El-Hack, M. A., Saeed, M., Arain, M. A., \& Elnesr, S. S. (2019). Humic acid as a feed additive in poultry diets: a review. Iranian journal of veterinary research, 20(3), 167.

Arief, M., N. Fitriani dan S. Subekti. 2014. Pengaruh Pemberian Probiotik Berbeda Pada Pakan Komersial Terhadap Pertumbuhan dan Efisiensi Pakan Ikan Lele Sangkuriang (Clarias Sp.). Jurnal Ilmiah Perikanan dan Kelautan Vol 6(1): $49-53$

Berian Jaya, dkk. 2013. Laju Pertumbuhan dan Tingkat Kelangsungan Hidup Benih
Fitria A. S. 2012. Analisi Kelulushidupan dan Pertumbuhan Benih Ikan Nila Larasati (Oreochromis niloticus) F5 D30-D70 Pada Berbagai Salinitas. Program Studi Budidaya Perairan, Jurusan Perikanan Fakultas Perikanan dan Ilmu Kelautan, Universitas Diponegoro. Journal Of Aquaculture Management anf Technology. 1(1): 18-34

Hakim Y. I. N., 2015. Langsung Hasil Ternak Lele Sangkuriang, Jakarta: Infra Pustaka. Hal 49

Hendri Ahmadi, et al. 2012. Pemberian Probioik dalam Pakan Terhadap Pertumbuhan Lele Sangkuriang (Clarias gariepinus) pada Pendederan II. Jurnal Perikanan dan Kelautan, Vol 3 No 4.

Hermawan, A. T. E. S., A. Sudaryono dan S. B Praitno. 2014. Pengaruh Padat Tebar Berbeda terhadap Pertumbuhan dan Kelulushidupan Benih Lele Clarias gariepinus dalam Media Bioflok. Journal of Aquaculture Management and Technology, 3 (3): 34-42.

Ihdaryanti M. A, 2011. Pengaruh Asam Humat dan Cara Pemberiannya Terhadap Pertumbuhan dan Produktivitas Tanaman Padi (Oryza sativa). SKRIPSI. Fakultas Pertanian Bogor. IPB

Kementrian Kelautan dan Perikanan. 2018. Laporan Tahunan Direktorat Produksi Tahun 2018. https://kkp.go.id/djpb/artikel/9004-kkpmendorong-kawasan-lele-digitalpertama-di-indonesia. Artikel. Diakses pada 10 December 2019.

Kementrian Pertanian, Badan Litbang Pertanian. 2013. Asam Humat, Senyawa Organik 
Journal of Aquaculture Science

DOI: https://doi.org/10.31093/joas.v6i1IS.151

Penghemat Pemakaian Pupuk Anorganik. Litbang.pertanian.go.id/infoaktual/1525/. Diakses pada 30 Oktober 2019.

Khairuman dan K. Amri. 2002. Budidaya Lele Dumbo Secara Intensif. Agromedia Pustaka. Jakarta. 84 hal.

Kholish M. 2008. Panduan Lengkap Agribisnis Lele, Jakarta : Penebar Swadaya. Hal 94.

Kodama, H \& Denso. 2007. Antitumor Effect of Humus Extract on Murine Transplantable L1210 Leukimia. Journal Veterinary Medical Science. 2007; 69(10):10691071.

Kusriningrum, R. S. 2008. Perancangan Percobaan. Universitas Airlangga. Surabaya. Hal. 165 - 173

Lestari A,. 2011. Prevalensi Ektoparasit Protozoa Tricodina sp. Pada Ikan Lele Dumbo (Clarias gariepinus) di Desa Ngabetan Kecamatan Cerme Kabupaten Gresik. SKRIPSI. ADLN. Perpustakaan Universitas Airlangga.

Lusiastuti, A. M., Septyan A., dan Reza S. 2017. Efektivitas Kombinasi Probiotik Mikroenkapsulasi Melalui Pakan Untuk Pengendalian Penyakit Motile Aeromonas Septicema Pada Ikan Lele, Clarias gariepinus. Jurnal Riset Akuakultur, 12 (2), 179-186.

Gufran. H. Kordi K. 2012. Kiat Sukses Pembesaran Lele Unggul, Yogyakarta. Lili Publisher. Hal 22

Mandasari D. 2016. Penambahan Asam Humat Dalam Pakan Untuk Meningkatkan Pertumbuhan Ikan Nila Oreochromis niloticus. Fakultas Perikanan dan Ilmu Kelautan. IPB

Medinawati, Novalina S., Yoel. 2011. Pemberian Pakan Yang Berbeda Terhadap Pertumbuhan dan Kelangsungan Hidup Benih Lele Dumbo (Clarias gariepinus). Media Litbang Sulteng IV(2) : 83-87.

Nur dan Abidin. 2011. Manajemen Pemeliharaan Udang Vaname (Litopenaeus vannamei). Direktorat Jendral Perikanan Budidaya Balai Besar Pengembangan Budidaya Air Payau. Jepara: 40.

Prihartono, R. E., J. Rasidik dan U. Asrie. 2000. Mengatasi Permasalahan Budidaya Lele
July 2021 Vol 6 Issue Spesial: 1-14

Online pada http://joas.co.id

Dumbo. Penebar Swadaya. Jakarta. 86 hal.

Putra, A. N. 2010. Kajian Probiotik, Prebiotik dan Sinbiotik untuk Meningkatkan Kinerja Pertumbuhan Ikan Nila (Oreochromisniloticus). Tesis. Program Pasca Sarjana. Institut Pertanian Bogor. Bogor. 91 hal.

Putra, D. A., Lisdiana dan T. A. Pribadi. 2014. RAM JET VENTILATION, Perubahan Struktur Morfologi dan Gambaran Mikroanatomi Insang Ikan Lele akibat Paparan Limbah Cair Pewarna Batik. Unnes Journal of Life Science, 3 (1): 5358 .

Rahardjo, M. F., D. S. Sjafei, R. Affandi dan Sulistiono. 2011. Iktiology. Lubuk Agung. Bandung. hal. 83-124.

Rahmawati, A. 2011. Isolasi dan Karakterisasi Asam Humat Dari Tanah Gambut. Jurnal PHENOMENON. Vol 2, No 1, Hal 117-136.

Rizky, R. B. 2019. Aplikasi Bacillus Dan Pseudomonas Dengan Kepadatan Berbeda Terhadap Total Bakteri Dan Total Vibrio Pada Saluran Pencernaan Udang Vanamei (Litopenaeus vannamei). Fakultas Perikanan dan Kelautan. Surabaya. Skripsi.

Rose D., Ardiningsih P., Idiawati P. 2018. Karakteristik Nata de Jackfruit (Artocarpus heterophyllus) Dengan Variasi Konsentrasi Starter Acetobacter xylinum. Jurnal Kimia Khatulistiwa. 7(4): $1-7$

Rousdy, D. W., \& Wijayanti, N. 2015. Profil Hematologi Dan Pertumbuhan Ikan Mas (Cyprinus carpio Linn.) Pada Pemberian Asam Humat Tanah Gambut Kalimantan. SEMIRATA 2015, 4(1).

Rudiyanti S, dan Ekasari D,. 2009. Pertumbuhan dan Survival Rate ikan mas (Cyprinus carpio) pada berbagai konsentrasi pestisida regent 0,3 G. Jurnal Saintek Perikanan 5(1): 39-47.

Sabana, Ady. 2017. Semakin Dekat dengan Ikan Lele, Pusat Pelatihan Kelautan dan Perikanan (PUSLAT KP). http://puslat1.kkp.go.id/puslatweb/artike 1.php? mod=view\&id=AR1D000102. Diakses 08 Desember 2017 
Journal of Aquaculture Science

DOI: https://doi.org/10.31093/joas.v6i1IS.151

Sambode, D., H. Pangkey dan S. Lantu. 2013. Pertumbuhan Cladocera jenis Chudoridae pada Media Kultur yang Berbeda. Budidaya Perairan, 1(2): 1-7.

Setiawan, A., R. Ariqoh., P. Tivani., 1. Pipih dan I. Pudjiastuti. 2016. "Bioflokulasi Sistem” Teknologi Budidaya Lele Tebar Padat Tinggi dengan Kaasitas $1 \mathrm{M}^{3} / 750$ Ekor dengan Flock Forming Bacteria. Inovasi Teknik Kimia, 1 (1): 45-49.

Suryaningsih, S. 2014. Biologi Ikan Lele. Bahan Penyuluhan pada Petani Ikan Desa Pingit, Kecamatan Rakit, Kabupaten Banjarnegara, 12 Agustus 2014. 9 hal.

Venn-Watson, S., C. R. Smith, and E. D. Jensen. 2008. Primary Bacterial Pathogens in Bottlenose Dolphins Tursiops truncatus: Needles in Haystacks of Commensal and Environmental Microbes. Disease of Aquatic Organisms. 79: 87-93

Wang, Q., Chen, Y.J., Yoo, J.S., Kim, H.J., Cho, I.H., Kim, I.H. Effects of Supplemental Humic Ssubstances on Growth Performance, Blood Characteristics and Meat Quality in Finishing Pigs. Livestock Science.2008; 117:270 274.doi:10.1016/j.livsci.2007.12.024
July 2021 Vol 6 Issue Spesial: 1-14

Online pada http://joas.co.id

Wijayanti, K. 2010. Pengaruh Pemberian Pakan Alami yang Berbeda Terhadap Sintasan dan Pertumbuhan Benih Ikan Palmas (Polyptelus senegalus senegalus Cuvier, 1829). Skripsi. Universitas Indonesia. Depok.

Wongsa P, Werukhamkul P. 2007. Product Development and Technical Service, Biosolution International. Thailand (TH): Bangkadi Industrial Park 134/4.

Yigit, M., E. S. Celik, Sebattin E., Sevdan Y. 2018. Effects of dietary humic acid on growth

performance,haemato-immunological and physiological responses andresistance of Rainbow trout,Oncorhynchus mykisstoYersiniaruckeri. Aquaculture Research. 49 (3338-3349)

Yılmaz, S., Ergun, S., Çelik, E. Ş., \& Yigit, M. (2018). Effects of dietary humic acid on growth performance, haemato-immunological and physiological responses and resistance of Rainbow trout, Oncorhynchus mykiss to Yersinia ruckeri. Aquaculture research, 49(10): 3338-3349 